\title{
Primary Malignant Melanoma of the Vagina in Bangladesh: Report of a Case Series and Review of the Literature
}

\author{
Shahana Pervin', Farzana Islam1, Annekathryn Goodman ${ }^{2,3 *}$ \\ ${ }^{1}$ Department of Gynecology, National Institute of Cancer Research and Hospital, Dhaka, Bangladesh \\ ${ }^{2}$ Division of Gynecologic Oncology, Vincent Obstetrics and Gynecology, Massachusetts General Hospital, \\ Boston, USA \\ ${ }^{3}$ Harvard School of Medicine, Boston, USA \\ Email: "agoodman@mgh.harvard.edu
}

Received 29 March 2016; accepted 25 April 2016; published 28 April 2016

Copyright (C) 2016 by authors and Scientific Research Publishing Inc.

This work is licensed under the Creative Commons Attribution International License (CC BY).

http://creativecommons.org/licenses/by/4.0/

c) (i) Open Access

\begin{abstract}
Objective: This study describes the characteristics of patients with primary malignant melanoma of the vagina and their treatment at National Institute of Cancer Research and Hospital in Dhaka, Bangladesh, from February 2013-January 2015. Materials/Methods: Eight patients with primary malignant melanoma of the vagina were identified. Medical records were reviewed for demographic information, treatment, and outcomes. This investigation was approved by the Ethics Committee of the National Institute of Cancer Research and Hospital. Results: The median age was 48 years (range: 35 - 65 years) and most patients were premenopausal. Seven of the eight patients presented with International Federation of Gynecology and Obstetrics (FIGO) stage II. The five patients had disease confined mainly to the upper and middle thirds of the vagina. One patient was diagnosed with stage IV disease. In two patients, cervical metastases were present. Almost all patients received radiotherapy. Two patients with stage II disease developed local recurrences within eighteen months. The one patient with stage IV disease died ten months after diagnosis. Conclusion: Primary malignant melanomas of the vagina are uncommon, highly aggressive tumors that are associated with poor overall survival. Surgery is the mainstay of treatment. Nearly $80 \%$ of vaginal melanomas will recur. Overall 5 -year survival ranges from $5 \%$ to $25 \%$. The size of the tumor (>than $3 \mathrm{~cm}$ ) and the presence of lymphadenopathy at diagnosis worsen the overall survival.
\end{abstract}

\section{Keywords}

Melanoma, Vaginal Cancer, Bangladesh

\footnotetext{
${ }^{*}$ Corresponding author.
}

How to cite this paper: Pervin, S., Islam, F. and Goodman, A. (2016) Primary Malignant Melanoma of the Vagina in Bangladesh: Report of a Case Series and Review of the Literature. Open Journal of Obstetrics and Gynecology, 6, 313-324. 


\section{Introduction}

Primary malignant melanoma of vagina (PMMV) is an extremely rare and highly aggressive tumor, with fewer than 500 cases reported worldwide [1]. It accounts for $5 \%$ of all vaginal malignancies and represents $0.2 \%$ to $0.8 \%$ of all malignant melanomas [2]. The amelanotic variety is exceedingly rare, accounting only $2 \%$ of all vaginal melanomas [3]. The estimated incidence of PMMV is between 0.26 and $0.46 / 1,000,000$ women per year [4] [5]. Unlike cutaneous melanomas secondary to sun-exposure, it is unknown whether the incidence of vaginal melanomas varies by geographic region. While there have been a few case reports, there have been no previous case series describing genital tract melanomas in Bangladesh or in South Asia in general [6]-[10].

The etiology of this rare malignancy is largely unknown. PMMV originates from the malignant transformation of melanocytes in the basal portion of vaginal mucosa. The somatic mutation profiles of mucosal melanomas show BRAF mutations, common in cutaneous melanomas, to be rare while $c-K I T$ mutations representing mutations of a type III transmembrane receptor tyrosine kinase are more common[11]. Early hematogenous metastasis is common due to the thin vaginal wall and rich surrounding lymphatic and vascular plexus and leads to a propensity for PMMV to recur at distant sites. Prognosis is worse than that of cutaneous melanoma, vulvar melanoma and other vaginal malignancies [2] [4] [5] [12].

There are no uniform treatment guidelines at present. While surgery is the primary treatment for vaginal melanoma, a combined modality approach with radiation and immunotherapy may improve survival [1] [13]-[17]. Prognosis is very poor even with aggressive surgery and adjuvant therapy.

We report the first case series of vaginal melanomas from Bangladesh.

\section{Methods}

PMMV are included in this study from the period January 2013 to January 2015 at National Institute of Cancer Research and Hospital (NICRH), Dhaka, Bangladesh. This investigation was approved by the Ethics Committee of the National Institute of Cancer Research and Hospital. For this review of eight patients, there were no indeterminate results, missing data, and data outliers.

Clinical characteristics were recorded including age, menopausal status and presenting symptoms. Tumor factors included tumor size, location and International Federation of Gynecology \& Obstetrics (FIGO) stage [18]. Treatment data included type of surgery performed, lymph node status and use of adjuvant therapy. Mean follow-up of patients has been three years. Most patients underwent either wide local excision (WLE) (with a margin $\leq 2 \mathrm{~cm}$ ) or radical excision. Radical excision involved a radical hysterectomy, vaginectomy, and inguinal-femoral and pelvic lymphadenectomy for cases where the tumor was located in the upper and middle third of vagina. Total or subtotal vaginectomy was performed for distal, lower vaginal lesions. Adjuvant therapy with radiation, and/or chemotherapy was given for all patients. External radiation was given using a cobalt machine with two-field technique to a dose of $55 \mathrm{~Gy}$. Chemotherapy with cisplatin and 5-fluoro-uracil concurrently with radiation was given to two patients as part of their primary therapy.

\section{Results}

NICRH is a government supported 300-bed hospital, which treats an average of 1000 new gynecologic cancer patients per year. Eight patients diagnosed with PMMV were identified. Patient demographics, tumor characteristics and treatment information are described in Table 1 and Table 2. The most frequent presenting symptoms were vaginal bleeding, followed by vaginal mass and vaginal discharge. Some patients had more than one symptom. The median age at diagnosis was 47.9 years (range, 35 - 65 years). Six out of eight (75\%) of patients were premenopausal. Four (50\%) patients had multifocal disease and three (37.5\%) had unifocal lesions. Five of eight patients (62.5\%) had disease confined to upper and middle third of vagina. One patient had disease confined to the lower vagina (Figure 1-informed consent was obtained from each patient to publish the pictures). Seven patients (87.5\%) had FIGO stage II cancers and one had stage IV malignancy based on direct invasion of the bladder. For two patients with stage II disease, metastases to the cervix were present. Seven patients underwent surgery and among them, four were treated by radical hysterectomy with vaginectomy and bilateral inguino-femoral and pelvic lymphadenectomy while three had wide local excisions of the vaginal tumors. A pelvic exenteration was recommended to the one patient with stage IV disease but she declined and received chemo-radiation. Adjuvant radiation was given to seven patients. Two patients received brachytherapy along with external beam radiation. Pelvic lymph nodes were involved in one of the four patients who underwent femoral 
Table 1. Clinical and tumor characteristics in seven patients with primary vaginal melanoma.

\begin{tabular}{|c|c|}
\hline Age & Number of Patients \\
\hline$<45$ & 6 \\
\hline$>45$ & 2 \\
\hline \multicolumn{2}{|l|}{ Menopausal Status } \\
\hline Premenopausal & 6 \\
\hline Postmenopausal & 2 \\
\hline \multicolumn{2}{|l|}{ Presenting Symptoms } \\
\hline Vaginal bleeding & 7 \\
\hline Vaginal mass & 2 \\
\hline Vaginal discharge & 3 \\
\hline \multicolumn{2}{|l|}{ FIGO Stage } \\
\hline I & -- \\
\hline II & 7 \\
\hline III & -- \\
\hline IV & 1 \\
\hline \multicolumn{2}{|l|}{ Tumor Size } \\
\hline$<3 \mathrm{~cm}$ & 3 \\
\hline$>3 \mathrm{~cm}$ & 5 \\
\hline \multicolumn{2}{|l|}{ Tumor Site } \\
\hline Upper and middle third of vagina & 5 \\
\hline Lower third of vagina & 3 \\
\hline \multicolumn{2}{|l|}{ Lesion Number } \\
\hline Multifocal & 4 \\
\hline Unifocal & 4 \\
\hline \multicolumn{2}{|l|}{ Pathology } \\
\hline Melanotic & 6 \\
\hline Amelanotic & 2 \\
\hline \multicolumn{2}{|l|}{ Lymph node Status } \\
\hline Positive & 1 \\
\hline Negative & 4 \\
\hline Unknown & 3 \\
\hline
\end{tabular}

Table 2. Treatment characteristics in seven patients with primary vaginal melanoma.

\begin{tabular}{cc}
\hline Surgical Intervention & Number of Patients \\
\hline $\begin{array}{c}\text { Wide local excision } \\
\text { Radical hysterectomy } \\
\text { Vaginectomy } \\
\text { Inguinal Pelvic lymphadenectomy } \\
\text { No surgery }\end{array}$ & 3 \\
\hline Radiation Therapy & 1 \\
\hline $\begin{array}{c}\text { Surgery with EBRT } \\
\text { Surgery with EBRT and ICRT } \\
\text { Surgery, chemotherapy and EBRT }\end{array}$ & 4 \\
\hline Chemotherapy & 2 \\
\hline Chemotherapy, surgery, EBRT \\
Chemotherapy with EBRT
\end{tabular}

EBRT: external beam radiotherapy; ICRT: intracavitary radiotherapy. 


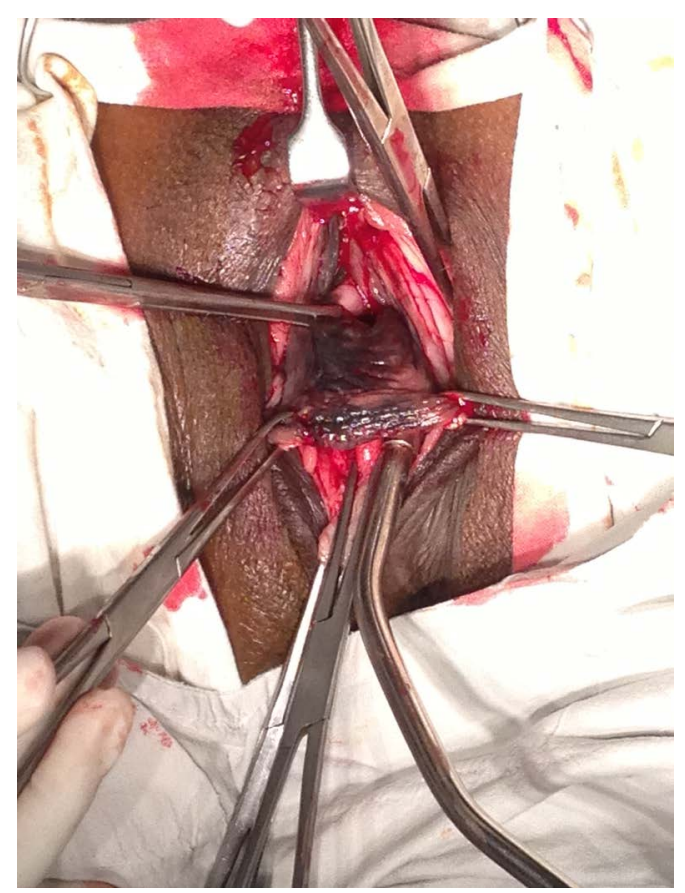

Figure 1. Stage II vaginal melanoma of the distal third of the vagina in the posterior vagina.

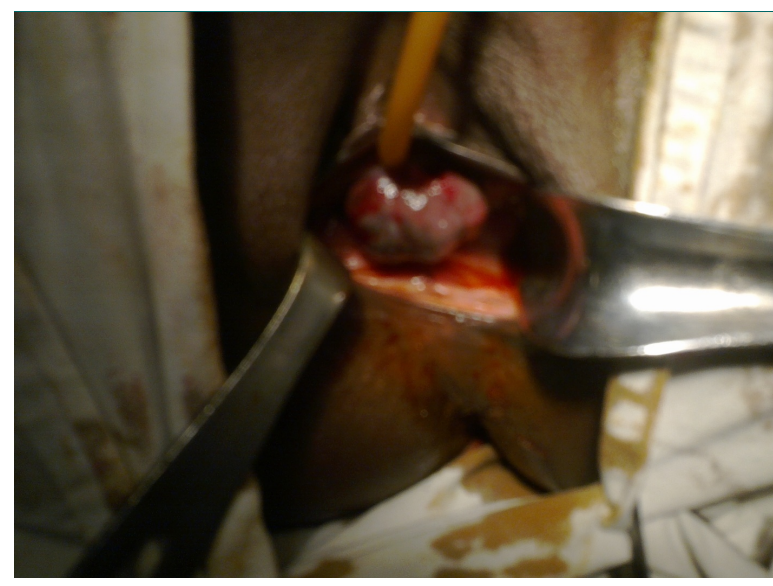

(a)

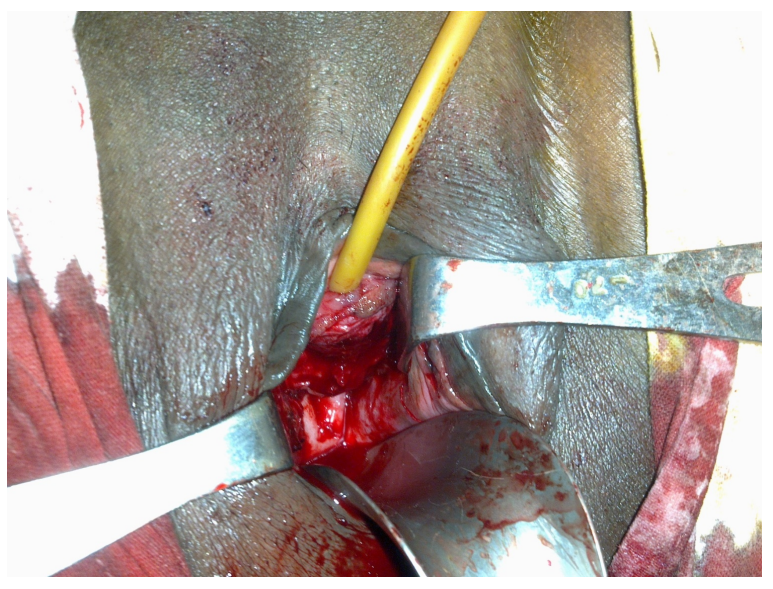

(b)

Figure 2. (a) Stage II vaginal melanoma of the distal third of the vagina in the periurethral region; (b) stage II vaginal melanoma of the distal third of the vagina: After wide local excision.

and pelvic lymphadenectomy. Lymphedema developed in the four patients who underwent lymphadenectomy.

On follow-up, two patients with stage II disease (one with positive lymph nodes and one with negative nodes) had recurrences in the pelvis. One patient, age 45 years, underwent a wide local excision followed by external and intracavitary radiation (Figure 2-informed consent was obtained from each patient to publish the pictures). The second patient, age 40 years, underwent a radical hysterectomy, bilateral inguinal-femoral and pelvic lymphadenectomy followed by external radiation. Both patients experienced vaginal recurrences within 18 months of therapy and are currently undergoing chemotherapy with cisplatin. The one patient with stage IV PMMV had progression of her cancer and died within one year of diagnosis. This patient, age 35 years, presented during the first trimester of pregnancy with a $7 \mathrm{~cm}$ vaginal mass with direct extension into the bladder (Figure 3-informed consent was obtained from each patient to publish the pictures). She declined a pelvic exenteration. After a pregnancy termination, she received chemotherapy and external beam radiation but rapidly recurred both locally and distantly. She died 10 months after diagnosis. 


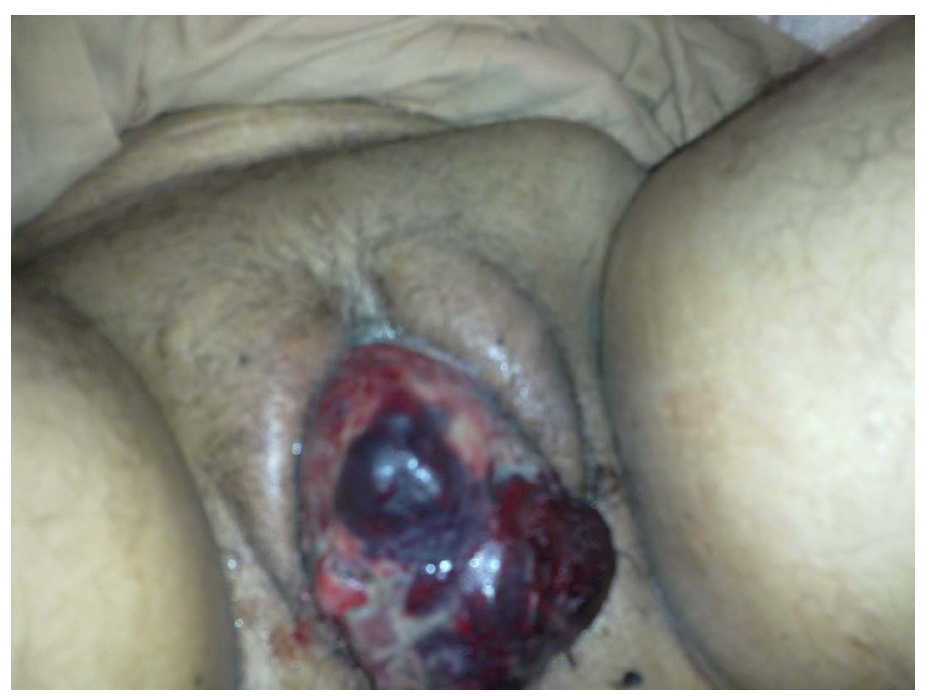

Figure 3. Stage IV vaginal melanoma with tumor prolapsing out of vagina with bilateral inguinal lymphadenopathy.

\section{Discussion}

We report on eight cases of vaginal melanoma seen in a two-year period at NICRH in Bangladesh. Bangladesh, a country of 166 million people, does not have a uniform cancer reporting system [19]. There are no national tumor registries and data collection and follow-up at individual hospitals is marginal so the true incidence and outcomes of cancers are unknown. While cervical cancer has been the most common gynecologic cancer in Bangladesh with at least 30 cases per 100,000 women, there is little information about other cancers of the lower genital tract [20]. A recent report detailed the first case series of squamous cell cancers of the vulvar seen at NICRH [21]. NICRH, a tertiary care, government hospital of 300 beds, is one of the few public hospitals devoted to the care of people with cancer in Bangladesh [22]. The need for cancer care in Bangladesh far outstrips the resources of this and other hospitals that provide oncologic services. At NICRH, there are currently four linear accelerators, two cobalt machines, and one brachytherapy machine that treat on average 400 cancer patients per day. As a consequence of wait times for radiation of 30 to 60 days, surgical interventions are considered whenever possible.

There is a growing literature of single-institution case reports and case series for PMMV around the world. Reports representative of the international experience with PVVM from the last 20 years are summarized in Table 3 and Table 4 [6]-[10] [16] [17] [23]-[57]. Of note, large series of patients with PMMV have required many decades of institutional experience [17] [29] [31]-[33] [35] [36] [38]-[47] [49] [54] [55] [58]. Overall, there do not seem to be geographic or ethnic variations in the clinical features of PMMV, or in the overall survival rates. From the surveillance, epidemiology, and end results (SEER) database in the United States from 1992 to 2005 , 125 vaginal melanomas were identified [4]. In combination with vulva melanomas, the age adjusted incidence rates ranged from 0.87 in African Americans to 1.03 in Asians to 1.9 in non-Hispanic whites. In another SEER analysis of 201 patients with vaginal melanoma treated from 1988 to 2008, the population was 73\% white, 11\% black, and 16\% Asian/American Indian [59]. Staging results showed 46\% FIGO stage I, 18\% stage II, 3\% stage III, and 3\% stage IV. A third SEER analysis compared the combined data from 762 patients with vulvar and vaginal melanomas to 55,485 patients with cutaneous melanomas from 1973 to 2008 [60]. In a multivariate analysis, age, stage, and positive lymph node status were independent negative prognostic factors for vulvar and vaginal melanomas whereas age, race, stage, radiation therapy, and lymph node status impacted survival negatively for cutaneous melanomas. The average age at diagnosis is in the sixth and seventh decades of life. The majority of women presented to medical attention with vaginal bleeding. The majority of vaginal melanomas are located in the lower third of the vagina [33] [55] [59]. In our patient series, the average age of 47 years was younger than other reports and the majority of our patients presented with upper vaginal masses.

Reviews of the largest case-series help to give a general picture of patient characteristics, therapeutic interventions, and outcomes. Forty-four patients over a 9-year period seen at Fudan University in Shanghai were treated with excisional surgery. Progression-free survival was dependent on depth of invasion, lymph nodes sta- 
Table 3. Case reports of primary malignant melanoma of the vagina.

\begin{tabular}{|c|c|c|c|c|c|c|}
\hline Country & Year & Age & FIGO & Treatment & $\begin{array}{l}\text { Follow-Up } \\
\text { (Months) }\end{array}$ & Outcome \\
\hline Japan [53] & 2015 & 59 & II & RH, V, DTIC, IM & 5 & Lung metastases \\
\hline Bulgaria [23] & 2014 & 71 & II & $\begin{array}{l}\text { RH, V, LN } \\
\text { IM, DTIC }\end{array}$ & 21 & Died 21 months \\
\hline China [31] & 2014 & 35 & II & $\mathrm{RH}, \mathrm{LN}, \mathrm{V}$ & 6 & Pelvic recurrence; lost to follow-up \\
\hline Denmark [54] & 2013 & 77 & II & exenteration & 7 & Recurrence at 7 months \\
\hline Morrocco [51] & 2013 & 70 & IV & imatinib & 18 & regression \\
\hline India [7] & 2013 & 60 & II & $\begin{array}{l}\text { WLE, EBRT } \\
\text { CT: TEM }\end{array}$ & 12 & Alive at one year \\
\hline Greece [24] & 2013 & 80 & II & WLE, ICRT & 5 & Died lung metastases at one year* \\
\hline Germany [55] & 2012 & 44 & III & exenteration & 4 & Died at 4 months \\
\hline India [10] & 2012 & 66 & II & WLE,EBRT & 12 & Died with widespread recurrence \\
\hline China [56] & 2011 & 54 & III & RH, V EBRT, IM, CT & 12 & Brain metastasis \\
\hline India [6] & 2009 & 60 & II & $\begin{array}{l}\text { WLE } \\
\text { DTIC }\end{array}$ & 12 & Alive one year \\
\hline Turkey [25] & 2009 & 51 & $!$ & $\begin{array}{c}\text { V, LN } \\
\text { DTIC, cispltin }\end{array}$ & 21 & $\begin{array}{l}\text { Nodal metastases at } 9 \text { months } \\
\text { Alive at } 21 \text { months }\end{array}$ \\
\hline Bangladesh [9] & 2008 & 52 & I & WLE, EBRT & -- & Lost to follow-up \\
\hline Nepal [8] & 2007 & 60 & II & WLE, EBRT & 6 & $\begin{array}{l}\text { Recurrence } 3 \text { months } \\
\text { Died at } 6 \text { months }\end{array}$ \\
\hline Germany [26] & 2007 & 58 & I & WLE, EBRT & 6 & Metastasized at 6 months \\
\hline Spain [27] & 2004 & 40 & I & $\begin{array}{l}\text { RH, V, LN } \\
\text { EBRT, IM }\end{array}$ & 8 & $\begin{array}{c}\text { Recurred in liver and ascites at } 7 \text { months } \\
\text { Died at } 8 \text { months }\end{array}$ \\
\hline South Africa [28] & 2004 & 49 & II & $\begin{array}{c}\text { WLE, IM } \\
\text { DTIC \& carboplatin }\end{array}$ & 24 & Alive at 2 years \\
\hline Israel [29] & 2002 & 67 & II & $\begin{array}{l}\text { WLE, EBRT } \\
\text { ICRT }\end{array}$ & 11 & Alive at 11 months \\
\hline Italy [15] & 1998 & 45 & IV & $\begin{array}{l}\text { Exenteration } \\
\text { DTIC } \\
\text { fotemustine }\end{array}$ & 12 & $\begin{array}{l}\text { Metastases at } 4 \text { months } \\
\text { Alive at } 12 \text { months }\end{array}$ \\
\hline USA [30] & 1998 & 55 & I & WLE, LN & 13 years & Alive at 13 years \\
\hline
\end{tabular}

CT chemotherapy; DTIC dacarbazine chemotherapy; EBRT: external beam radiotherapy; ICRT: intracavitary radiotherapy; LN lymphadenectomy; RH radical hysterectomy; TEM: temozolamide chemotherapy; V vaginectomy; WLE: wide local excision; "

Table 4. Case series of primary malignant melanoma of the vagina.

\begin{tabular}{|c|c|c|c|c|}
\hline Country & $\begin{array}{l}\text { Dates } \\
\text { of Care }\end{array}$ & $\begin{array}{c}\text { \# of } \\
\text { Patients }\end{array}$ & Treatment & Recurrence and Survival \\
\hline Bangladesh & 2013-2015 & 8 & $\begin{array}{l}4 \text { RH V LN } \\
3 \text { WLE }\end{array}$ & $43 \%$ recurrence; $14 \%$ died in two years \\
\hline China [32] & 2002-2011 & 44 & $\begin{array}{l}21 \text { WLE } \\
20 \text { RH V } \\
5 \text { EBRT,30 IM, } 11 \text { CT }\end{array}$ & $\begin{array}{l}68.2 \% \text { recurred; } 47.7 \% \text { died } \\
5 \text { lived longer than } 5 \text { years }\end{array}$ \\
\hline France [52] & $2000-2010$ & 6 & WLE & Median progression free survival 10.5 months \\
\hline USA [67] & 1993-2012 & 14 & $\begin{array}{l}5 \mathrm{WLE} \\
3 \mathrm{WLE}, \mathrm{LN} \\
3 \text { radical excision } \\
3 \text { exenteration } \\
2 \text { preop CT, } 1 \text { EBRT }\end{array}$ & $\begin{array}{l}\text { Recurrence in } 10 \text { of } 14 \text { patients } \\
\text { Median time to recurrence } 6 \text { months } \\
\text { Median overall survival } 2.1 \text { years }\end{array}$ \\
\hline $\begin{array}{l}\text { France [58] } \\
12 \text { institutions }\end{array}$ & 1990-2007 & 46 & $\begin{array}{l}4 \text { exenteration } \\
19 \mathrm{WLE} \\
7 \mathrm{~V} \\
9 \mathrm{RH} \text { V LN } \\
5 \mathrm{EBRT}, 6 \mathrm{ICRT} \\
6 \mathrm{CT}, 4 \mathrm{IM}\end{array}$ & $\begin{array}{l}\text { Median relapse free survival } 10.9 \text { months } \\
\text { Median overall survival } 28.4 \text { months }\end{array}$ \\
\hline
\end{tabular}




\section{Continued}

\begin{tabular}{|c|c|c|c|c|}
\hline USA [30] & 1980-2009 & 37 & $\begin{array}{l}28 \text { WLE } \\
5 \text { exenteration } \\
5 \text { EBRT, CT }\end{array}$ & $\begin{array}{l}\text { Progression-free survival: } 11.4 \text { months, } \\
\text { Overall survival: } 19 \text { months. }\end{array}$ \\
\hline USA [57] & 1970-2009 & 15 & WLE, EBRT, CT, IM & 2/15 alive over 8 years follow-up \\
\hline China [34] & $1970-2005$ & 31 & $\begin{array}{l}15 \text { Surgery \& IM } \\
7 \text { surgery } \\
4 \text { CT \& IM } \\
3 \text { CT } \\
2 \text { no treatment }\end{array}$ & $35.5 \%$ recurrence; $32.3 \% 5$ year survival \\
\hline USA [35] & 1976-1986 & 5 & $\begin{array}{l}5 \text { WLE } \\
3 \text { CT, IM }\end{array}$ & Time to recurrence 7 months; mean survival 31 months \\
\hline USA [36] & 1970-2002 & 26 & $\begin{array}{l}7 \text { exenteration } \\
10 \text { WLE } \\
3 \text { RH V; } 1 \text { V } \\
3 \text { EBRT only }\end{array}$ & $\begin{array}{l}\text { Fifteen patients died of the disease ( } 3 \text { - } 83 \text { months) } \\
\text { Four patients no evidence of disease ( } 5 \text { - } 24 \text { months) } \\
\text { Four patients alive with disease ( } 6 \text { - } 276 \text { months) }\end{array}$ \\
\hline USA [37] & $1977-2001$ & 35 & $\begin{array}{l}10 \text { WLE } \\
2 \mathrm{~V} \\
10 \mathrm{RH} \mathrm{V} \\
2 \text { exenteration } \\
11 \text { EBRT, } 26 \text { IM or CT }\end{array}$ & $\begin{array}{l}\text { Median survival } 20 \text { months } \\
\text { Surgical therapy: median survival } 25 \text { months } \\
\text { Radiation therapy: median survival } 13 \text { months }\end{array}$ \\
\hline $\begin{array}{l}\text { United Kingdom } \\
\text { [50] }\end{array}$ & $1975-2000$ & 9 & $\begin{array}{l}2 \text { EBRT } \\
1 \text { RH,V } \\
6 \text { WLE }\end{array}$ & Median survival 24 months (range 4 to 60 months) \\
\hline China [16] & 1979-1997 & 9 & 9 surgery, CT, IM & $20 \%$ 5-year survival; one long term survivor at 19 years \\
\hline USA [38] & 1990 & 10 & 10 surgery, EBRT, CT & $\begin{array}{l}\text { Mean time to recurrence: } 8 \text { months } \\
\text { Mean survival: } 15 \text { months }\end{array}$ \\
\hline Austria [39] & 1982-1996 & 14 & $\begin{array}{l}7 \text { biopsy } \\
5 \text { WLE } \\
1 \text { RH V } \\
1 \text { exenteration }\end{array}$ & $\begin{array}{l}\text { Mean survival } 10 \text { months (range } 1 \text { - 153) } \\
21 \% \text { 5-year survival }\end{array}$ \\
\hline USA [40] & 1966-1996 & 7 & $\begin{array}{l}2 \text { WLE } \\
2 \text { WLE, EBRT } \\
2 \text { ICRT } \\
1 \text { exenteration }\end{array}$ & $\begin{array}{l}\text { Median time to death } 20 \text { months ( } 2 \text { ot } 48 \text { months) } \\
\text { All Dead of disease }\end{array}$ \\
\hline USA [41] & 1982-1996 & 13 & $\begin{array}{l}5 \mathrm{~V} \\
9 \mathrm{WLE}\end{array}$ & 64\% Estimated 5-year survival \\
\hline USA [42] & 1972-1992 & 8 & $\begin{array}{l}4 \text { conservative: WLE, CT, } \\
\text { EBRT } \\
\text { 4 Radical: exent, RH }\end{array}$ & $\begin{array}{l}4 \text { patients radical surgery: } 75 \% \text { 2-year survival } \\
4 \text { patients conservative surgery: } 0 \% \text { 2-year survival }\end{array}$ \\
\hline Italy [43] & 1969-1993 & 20 & 15 WLE & $\begin{array}{l}15 \text { evaluable patients; } 2 \text { died postoperatively } \\
\text { All patients died of disease; median survival } 19 \text { months }\end{array}$ \\
\hline USA [44] & 1986-1992 & 4 & 4 exenteration & $\begin{array}{l}\text { All underwent pelvic exenteration; } \\
\text { One post operative death } \\
\text { Three patients alive at } 31 \text {-to } 97 \text { months }\end{array}$ \\
\hline Hong Kong [45] & $1978-1990$ & 10 & $\begin{array}{l}1 \text { exenteration, CT } \\
2 \mathrm{RH} \text { V } \\
3 \mathrm{WLE} \\
3 \mathrm{EBRT} \pm \mathrm{CT}\end{array}$ & $\begin{array}{l}\text { Five patients died } 2 \text { - } 22 \text { months } \\
\text { Five patients median survival } 18 \text { months }\end{array}$ \\
\hline USA [46] & $1936-1988$ & 15 & $\begin{array}{l}3 \mathrm{WLE} \\
2 \mathrm{RH} \mathrm{V} \\
5 \mathrm{~V} \text {, vulvectomy } \\
3 \text { exenteration } \\
2 \text { EBRT }\end{array}$ & $\begin{array}{l}17.4 \% 5 \text {-year survival } \\
\text { Two patients survival more than } 5 \text { years }\end{array}$ \\
\hline Spain [47] & 1984, 1986 & 2 & $\begin{array}{l}1 \mathrm{RH} \mathrm{V} \\
1 \mathrm{EBRT}\end{array}$ & Died at 4 and 6 months \\
\hline Sweden [48] & $1960-1984$ & 26 & Not stated & 13\% 5-year survival \\
\hline USA [49] & $1935-1976$ & 19 & $\begin{array}{l}7 \text { RH V } \\
8 \text { WLE, EBRT } \\
4 \text { EBRT, ICRT }\end{array}$ & $\begin{array}{l}21 \% \text { 5-year survival } \\
\text { One long-term survivor at } 14 \text { years }\end{array}$ \\
\hline
\end{tabular}

CT chemotherapy; EBRT: external beam radiotherapy; ICRT: intracavitary radiotherapy; IM: immunotherapy; LN lymphadenectomy; RH radical hysterectomy; V vaginectomy; WLE: wide local excision. 
tus and the addition of postoperative radiotherapy [38]. In another series over a 35-year interval in Guangzhou, China, survival of the 8 out of 31 patients correlated both with smaller tumor size and the addition of immunotherapy [35]. In this small cohort, the five-year survival rates of women who received surgery plus interferon immunotherapy versus surgery alone was $47 \%$ and $29 \%$ respectively. For 37 cases of vaginal melanoma identified over a 29-year period, treatment ranged from wide local or radical excision (76\% of patients) to pelvic exenteration (14\% of patients) [33]. Ten percent of patients received radiotherapy and/or chemotherapy. Eightynine percent of women recurred within two years. Recurrence was local in seven patients (22\%), distant in 20 (63\%), and both local and distant in five (15\%). The most common sites of distant recurrence were lungs and liver. Median progression-free survival was 11.4 months, and median overall survival was 19 months [33].

One retrospective, multi-institution study collected information on 54 patients with PMMV from 12 institutions over a 17-year period [58]. Forty-six patients were treated with curative intent (Table 4) and 8 patients received palliative management. The FIGO stage breakdown was $70 \%$ stage I, $12.5 \%$ stage II, $15 \%$ stage III, and $2.5 \%$ stage IV. All 46 patients had $c$-KIT testing by immunohistochemistry, which was positive in $80.6 \%$ of pathologic specimens. While recurrence rates were higher for patients who had $c$-KIT mutations, by univariate analysis, positivity did not correlate with overall survival.

Overall, prognostic factors include tumor size, depth of invasion, mitotic counts, and lymph node involvement [38] [55]. Lesions less than $3 \mathrm{~cm}$ have better survival than lesions greater than $3 \mathrm{~cm}$. Even though the majority of PMMV presenting at the early FIGO stages of I and II, 5-year survival rate ranges from 0\% to 21\%. The twoyear survival rate for our patients is $86 \%$. Our recurrence rates and survival over a 2-year period appear better than noted in other reports but our follow-up time is short.

In South Asia, there have been several case reports of PMMV [6]-[10]. Three cases have been reported from India, a 60-year-old menopausal woman with a $3 \mathrm{~cm}$ lesion in the lower vagina treated by excision and radiation, and a 36-year-old with a $7.5 \mathrm{~cm}$ lesion treated with WLE and chemotherapy, both disease-free at one year and a 66-year-old who died within a year after WLE and radiation [6]-[8]. A case report from Nepal describes a 60-year-old with a $7 \mathrm{~cm}$ lesion treated with WLE, radiation, and chemotherapy, who died from widespread metastases within six months [9]. In 2008, the first case of vaginal melanoma was reported in Bangladesh [10]. The patient was a 52-year-old postmenopausal woman with a $4 \mathrm{~cm}$ lesion in the lower vagina treated by surgical excision followed by radiotherapy. The paucity of prior reports from South Asia may reflect the challenges of data collection and follow-up in this resource-limited region. Our two-year experience of eight patients suggests an under-reported incidence of PMMV.

Existing literature has detailed the treatment options of surgical excision, and radiation [1]. There are scattered reports on both chemotherapy and immunotherapy [27] [35]. The radical nature and extent of surgery and the addition of adjuvant therapy may influence the prognosis but reports are mixed [41] [42] [47]. Surgery may be the only potentially curative treatment for local disease. Surgical management ranges from either by wide local excision (WLE) to a more radical approach including full vaginectomy or pelvic exenteration. Radical surgery has been promoted as the preferred approach to reduce local recurrence and improve survival [41] [47] [49]. Recent reports have argued that WLE can achieve equivalent survival rates to more radical resections [29] [31] [33] [36] [39] [42] [44] [45] [61]. There was no correlation between type of surgery and survival greater than five years in one case review of 21 long-term survivors [55]. In a series of 85 patients with all types of lower genital tract melanomas including 15 PMMV, survival for those who could not undergo surgery was significantly worse than for those where WLE was possible [57]. However, treatment should still be individualized based on the size and location of disease. If local excision is impossible because of inability to get free margins, radical surgery may be reasonable to completely remove the visible tumor. Four of our patients underwent radical excision and three underwent wide local excisions based on the locations and the size of the tumors. Role of lymphadenectomy is controversial [1] [33] [39] [41] [62]. Recent studies have argued that lymphadenectomy is not therapeutic and carries significant morbidity [33] [36] [39] [61]. All of our patients who underwent lymphadenectomy developed lymphedema. Lymph node status may have a prognostic significance and as better therapies are developed, this may be important for treatment planning [33]. Sentinel lymph node biopsy to confirm node status has replaced full lymphadenectomy in the setting of radiological and clinically negative lymph nodes in vulvar melanoma. Due to its low morbidity, it has recently gained popularity in both cutaneous and vaginal melanoma [51] [62]-[64].

Radiation therapy has been routinely used as adjuvant therapy although there are no large series comparing surgery alone to surgery with radiation. A recent study of carbon ion radiotherapy for 23 patients with genital 
mucosal melanoma showed a recurrence rate of $61 \%$ with a median follow-up of 17 months and a $53 \%$ threeyear survival rate [65]. Seven of our eight patients underwent surgery with adjuvant radiotherapy, which is similar with other reports [1] [5]. Two patients are currently alive with vaginal recurrences and carry a very guarded prognosis. One patient with stage IV PMMV died within a year of diagnosis.

Since the first report of vaginal melanoma in 1887, there has been a slow accrual of case studies and case reports over the past 128 years [66]. PMMV are uncommon, highly aggressive tumors that are associated with poor overall survival. Based on case series, PMMV makes up between $2 \%$ to $11 \%$ of all primary vaginal cancers and less than $1 \%$ of all melanomas [12] [49] [55]. Nearly $80 \%$ of vaginal melanomas will recur. Current collective experience suggests that surgical excision followed by adjuvant therapy such as radiation and immunotherapy are the best therapeutic interventions available. Chemotherapy plays an unclear role, as data is extremely limited [67]. Tumor registries and outcome tracking will be important to fully define the incidence and behaviors of these rare tumors in resource-limited regions such as South Asia. In resource rich countries, $c$-KIT mutations should be tested and participation in clinical trials has been recommended [14].

\section{Conflict of Interest}

The authors have no disclosures

\section{References}

[1] Piura, B. (2008) Management of Primary Melanoma of the Female Urogenital Tract. The Lancet Oncology, 9, 973-981. http://dx.doi.org/10.1016/S1470-2045(08)70254-7

[2] McLaughlin, C.C., Wu, X.C., Jemal, A., Martin, H.J., Roche, L.M. and Chen, V.W. (2005) Incidence of Noncutaneous Melanomas in the U.S. Cancer, 103, 1000-1007. http://dx.doi.org/10.1002/cncr.20866

[3] Grenader, T., Isacson, R., Reinus, C., Rosengarten, O., Barenholz, O., Hyman, J., Gabizon, A. and Beller, U. (2008) Primary Amelanotic Melanoma of the Vagina. Onkologie, 31, 474-476. http://dx.doi.org/10.1159/000142398

[4] Hu, D.N., Yu, G.P. and McCormick, S.A. (2010) Population-Based Incidence of Vulvar and Vaginal Melanoma in Various Races and Ethnic Groups with Comparisons to Other Site-Specific Melanomas. Melanoma Research, 20, 153158. http://dx.doi.org/10.1097/CMR.0b013e32833684e8

[5] Weinstock, M.A. (1994) Malignant Melanoma of the Vulva and Vagina in the United States: Patterns of Incidence and Population-Based Estimates of Survival. American Journal of Obstetrics \& Gynecology, 171, 1225-1230. http://dx.doi.org/10.1016/0002-9378(94)90137-6

[6] Biswas, B., Garain, P., Dasgupta, S., Sen, S., Biswas, P. and Dasgupta, C. (2009) Malignant Melanoma of Vagina-A Case Report. Journal of the Indian Medical Association, 107, 247-248.

[7] Chaudhuri, S., Das, D., Chowdhury, S. and Gupta, A.D. (2013) Primary Malignant Melanoma of the Vagina: A Case Report and Review of Literature. South Asian Journal of Cancer, 2, 4. http://dx.doi.org/10.4103/2278-330X.105861

[8] Chauhan, N., Gaur, D.S. and Pathak, V.P. (2012) Round Cell Vaginal Malignant Melanoma: A Rare Entity. Sultan Qaboos University Medical Journal, 12, 508-511. http://dx.doi.org/10.12816/0003179

[9] Ghosh, A., Pradhan, S., Swami, R., Kc, S.R. and Talwar, O. (2007) Primary Malignant Melanoma of Vagina—A Case Report with Review of Literature. Journal of Nepal Medical Associationc, 46, 203-205.

[10] Sultana, N., Ali, C.M., Khanam, R.A. and Khatan, M. (2008) Malignant Melanoma of the Vagina—A Case Report. Journal of Bangladesh College of Physicians and Surgeons, 26, 103-105.

[11] Tacastacas, J.D., Bray, J., Cohen, Y.K., Arbesman, J., Kim, J., Koon, H.B., Honda, K., Cooper, K.D. and Gerstenblith, M.R. (2014) Update on Primary Mucosal Melanoma. Journal of the American Academy of Dermatology, 71, 366-375. http://dx.doi.org/10.1016/i.jaad.2014.03.031

[12] Creasman, W.T., Phillips, J.L. and Menck, H.R. (1998) The National Cancer Data Base Report on Cancer of the Vagina. Cancer, 83, 1033-1040. http://dx.doi.org/10.1002/(SICI)1097-0142(19980901)83:5<1033::AID-CNCR30>3.0.CO;2-6

[13] Carvajal, R.D., Spencer, S.A. and Lydiatt, W. (2012) Mucosal Melanoma: A Clinically and Biologically Unique Disease Entity. Journal of the National Comprehensive Cancer Network, 10, 345-356.

[14] Leitao Jr., M.M. (2014) Management of Vulvar and Vaginal Melanomas: Current and Future Strategies. American Society of Clinical Oncology Educational Book, e277-e281. http://dx.doi.org/10.14694/EdBook_AM.2014.34.e277

[15] Signorelli, M., Lissoni, A.A., Garbi, A., Perego, P. and Mangioni, C. (2005) Primary Malignant Vaginal Melanoma Treated with Adriamycin and Ifosfamide: A Case Report and Literature Review. Gynecologic Oncology, 97, 700-703. http://dx.doi.org/10.1016/j.ygyno.2005.02.013 
[16] Stellato, G., Iodice, F., Casella, G., Fortuna, G., Tramontana, R., di Bonito, M. and Tramontana, S. (1998) Primary Malignant Melanoma of the Vagina: Case Report. European Journal of Gynaecological Oncology, 19, 186-188.

[17] Wang, Y., Chang, W. and Pu, D. (1997) [Clinical Analysis of 15 Patients with Primary Malignant Melanoma in the Genital Tract]. Chinese Journal of Obstetrics and Gynecology, 32, 226-228.

[18] FIGO Committee on Gynecologic Oncology (2009) Current FIGO Staging for Cancer of the Vagina, Fallopian Tube, Ovary, and Gestational Trophoblastic Neoplasia. International Journal of Gynecology \& Obstetrics, 105, 3-4. http://dx.doi.org/10.1016/j.ijgo.2008.12.015

[19] CIA World Factbook: Bangladesh. Accessed 19 April 2015. https://www.cia.gov/library/publications/the-world-factbook/geos/bg.html

[20] Hussain, S.A. and Sullivan, R. (2013) Cancer Control in Bangladesh. Japanese Journal of Clinical Oncology, 43, 1159-1169. http://dx.doi.org/10.1093/jico/hyt140

[21] Pervin, S. and Goodman, A. (2013) Treatment Outcome of Women with Vulvar Cancer Treated in Bangladesh. Journal of US-China Medical Science, 10, 134-138.

[22] NICRH National Institute of Cancer Research and Hospital 2015. Accessed 19 April 2015. http://nicrhbd.org/

[23] Androutsopoulos, G., Terzakis, E., Ioannidou, G., Tsamandas, A. and Decavalas, G. (2013) Vaginal Primary Malignant Melanoma: A Rare and Aggressive Tumor. Case Reports in Obstetrics and Gynecology, 2013, Article ID: 137908. http://dx.doi.org/10.1155/2013/137908

[24] Baloglu, A., Bezircioglu, I., Cetinkaya, B. and Yavuzcan, A. (2009) Primary Malignant Melanoma of the Vagina. Archives of Gynecology and Obstetrics, 280, 819-822. http://dx.doi.org/10.1007/s00404-009-1009-0

[25] Betschart, C., von Orelli, S., Mihic, D. and Fink, D. (2006) [Primary Malignant Melanoma of the Vagina-Case Report and Review of the Literature]. Gynäkol Geburtshilfliche Rundsch, 47, 39-44. http://dx.doi.org/10.1159/000098124

[26] Moodley, M., Daya, M. and Moodley, J. (2004) Vaginal Malignant Melanoma: A Case Report and Literature Review. International Journal of Gynecological Cancer, 14, 687-689. http://dx.doi.org/10.1111/j.1048-891X.2004.14430.x

[27] Moros, M.L., Ferrer, F.P., Mitchell, M.J., Romeo, J.A. and Lacruz, R.L. (2004) Primary Malignant Melanoma of the Vagina. Poor Response to Radical Surgery and Adjuvant Therapy. European Journal of Obstetrics \& Gynecology and Reproductive Biology, 113, 248-250. http://dx.doi.org/10.1016/j.ejogrb.2003.06.014

[28] Tsvetkov, C., Gorchev, G., Tomov, S., Hinkova, N., Nikolova, M. and Veselinova, T. (2014) [Primary Malignant Melanoma of the Vagina and Treatment Options: A Case Report]. Akusherstvo i Ginekologiia, 53, 35-40.

[29] Borazjani, G., Prem, K.A., Okagaki, T., Twiggs, L.B. and Adcock, L.L. (1990) Primary Malignant Melanoma of the Vagina: A Clinicopathological Analysis of 10 Cases. Gynecologic Oncology, 37, 264-267. http://dx.doi.org/10.1016/0090-8258(90)90345-L

[30] Brand, E., Fu, Y.S., Lagasse, L.D. and Berek, J.S. (1989) Vulvovaginal Melanoma: Report of Seven Cases and Literature Review. Gynecologic Oncology, 33, 54-60. http://dx.doi.org/10.1016/0090-8258(89)90603-3

[31] Buchanan, D.J., Schlaerth, J. and Kurosaki, T. (1998) Primary Vaginal Melanoma: Thirteen-Year Disease-Free Survival after Wide Local Excision and Review of Recent Literature. American Journal of Obstetrics \& Gynecology, 178, 1177-1184. http://dx.doi.org/10.1016/S0002-9378(98)70320-5

[32] Chen, L., Xiong, Y., Wang, H., Liang, L., Shang, H. and Yan, X. (2014) Malignant Melanoma of the Vagina: A Case Report and Review of the Literature. Oncology Letters, 8, 1585-1588. http://dx.doi.org/10.3892/ol.2014.2357

[33] Frumovitz, M., Etchepareborda, M., Sun, C.C., Soliman, P.T., Eifel, P.J., Levenback, C.F. and Ramirez, P.T. (2010) Primary Malignant Melanoma of the Vagina. Obstetrics \& Gynecology, 116, 1358-1365. http://dx.doi.org/10.1097/AOG.0b013e3181fb8045

[34] Gupta, D., Malpica, A., Deavers, M.T. and Silva, E.G. (2002) Vaginal Melanoma: A Clinicopathologic and Immunohistochemical Study of 26 Cases. The American Journal of Surgical Pathology, 26, 1450-1457. http://dx.doi.org/10.1097/00000478-200211000-00007

[35] Huang, Q., Huang, H., Wan, T., Deng, T. and Liu, J. (2013) Clinical Outcome of 31 Patients with Primary Malignant Melanoma of the Vagina. Journal of Gynecologic Oncology, 24, 330-335. http://dx.doi.org/10.3802/jgo.2013.24.4.330

[36] Miner, T.J., Delgado, R., Zeisler, J., Busam, K., Alektiar, K., Barakat, R. and Poynor, E. (2004) Primary Vaginal Melanoma: A Critical Analysis of Therapy. Annals of Surgical Oncology, 11, 34-39. http://dx.doi.org/10.1007/BF02524343

[37] Piura, B., Rabinovich, A. and Yanai-Inbar, I. (2002) Primary Malignant Melanoma of the Vagina: Case Report and Review of Literature. European Journal of Gynaecological Oncology, 23, 195-198.

[38] Xia, L., Han, D., Yang, W., Li, J., Chuang, L. and Wu, X. (2014) Primary Malignant Melanoma of the Vagina: A Retrospective Clinicopathologic Study of 44 Cases. International Journal of Gynecological Cancer, 24, 149-155. http://dx.doi.org/10.1097/IGC.0000000000000013 
[39] Cobellis, L., Calabrese, E., Stefanon, B. and Raspagliesi, F. (2000) Malignant Melanoma of the Vagina. A Report of 15 Cases. European Journal of Gynaecological Oncology, 21, 295-297.

[40] Ferrer, J., Zapatero, H.A., Coto, L.P., Diaz, L. and Perez, C.R. (1995) Vaginal Melanoma. Report of Two Cases and Review of the Literature. European Journal of Gynaecological Oncology, 16, 190-194.

[41] Geisler, J.P., Look, K.Y., Moore, D.A. and Sutton, G.P. (1995) Pelvic Exenteration for Malignant Melanomas of the Vagina or Urethra with over $3 \mathrm{~mm}$ of Invasion. Gynecologic Oncology, 59, 338-341. http://dx.doi.org/10.1006/gyno.1995.9966

[42] Irvin Jr., W.P., Bliss, S.A., Rice, L.W., Taylor Jr., P.T. and Andersen, W.A. (1998) Malignant Melanoma of the Vagina and Locoregional Control: Radical Surgery Revisited. Gynecologic Oncology, 71, 476-480. http://dx.doi.org/10.1006/gyno.1998.5188

[43] Khoo, U.S., Collins, R.J. and Ngan, H.Y. (1991) Malignant Melanoma of the Female Genital Tract. A Report of Nine Cases in the Chinese of Hong Kong. Pathology, 23, 312-317. http://dx.doi.org/10.3109/00313029109063595

[44] Konstadoulakis, M.M., Ricaniadis, N., Driscoll, D.L. and Karakousis, C.P. (1994) Malignant Melanoma of the Female Genital System. European Journal of Surgical Oncology, 20, 141-145.

[45] Petru, E., Nagele, F., Czerwenka, K., Graf, A.H., Lax, S., Bauer, M., Pehamberger, H. and Vavra, N. (1998) Primary Malignant Melanoma of the Vagina: Long-Term Remission Following Radiation Therapy. Gynecologic Oncology, 70, 23-26. http://dx.doi.org/10.1006/gyno.1998.4982

[46] Reid, G.C., Schmidt, R.W., Roberts, J.A., Hopkins, M.P., Barrett, R.J. and Morley, G.W. (1989) Primary Melanoma of the Vagina: A Clinicopathologic Analysis. Obstetrics \& Gynecology, 74, 190-199.

[47] Van Nostrand, K.M., Lucci 3rd, J.A., Schell, M., Berman, M.L., Manetta, A. and DiSaia, P.J. (1994) Primary Vaginal Melanoma: Improved Survival with Radical Pelvic Surgery. Gynecologic Oncology, 55, 234-237. http://dx.doi.org/10.1006/gyno.1994.1283

[48] Bennani, A., El Fatemi, H., Erraghay, S. and Amarti, A. (2014) Le Mã@Lanome Primitif De La Muqueuse Gã@Nitale Fã@Minine: Ã Propos De Trois Observations Et Revue De Littã@Rature. Pan African Medical Journal, 16, 19378688.

[49] Chung, A.F., Casey, M.J., Flannery, J.T., Woodruff, J.M. and Lewis Jr., J.L. (1980) Malignant Melanoma of the Vagina-Report of 19 Cases. Obstetrics \& Gynecology, 55, 720-727.

[50] Gauthier, T., Uzan, C., Gouy, S., Kane, A., Calvacanti, A., Mateus, C., Robert, C., Kolb, F. and Morice, P. (2012) [Malignant Melanoma of the Vagina: Pejorative Location]. Gynécologie Obstétrique \& Fertilité, 40, 273-278. http://dx.doi.org/10.1016/j.gyobfe.2011.11.005

[51] Ishida, H., Nagai, T., Sato, S., Honda, M., Uotani, T., Samejima, K., Hanaoka, T., Akahori, T., Takai, Y. and Seki, H. (2015) Concomitant Sentinel Lymph Node Biopsy Leading to Abbreviated Systematic Lymphadenectomy in a Patient with Primary Malignant Melanoma of the Vagina. SpringerPlus, 4, 102. http://dx.doi.org/10.1186/s40064-014-0773-X

[52] Kahr, H.S., Mejlgaard, E. and Lund, B. (2013) Primært malignt melanom i vagina. Ugeskrift for Laeger, 175, $133-134$.

[53] Kühn, F., Dieterich, M., Klar, E., Gerber, B. and Prinz, C. (2012) Primary Malignant Vaginal Melanoma—Case Report and Review of the Literature. Geburtshilfe und Frauenheilkunde, 72, 740-743. http://dx.doi.org/10.1055/s-0032-1315006

[54] Ragnarsson-Olding, B., Johansson, H., Rutqvist, L.-E. and Ringborg, U. (1994) Malignant Melanoma of the Vulva and Vagina: Trends in Incidence, Age Distribution, and Long-Term Survival Among 245 Consecutive Cases in Sweden, 1960-1984. Obstetrical \& Gynecological Survey, 49, 32. http://dx.doi.org/10.1097/00006254-199401000-00017

[55] Tjalma, W.A., Monaghan, J.M., de Barros Lopes, A., Naik, R. and Nordin, A. (2001) Primary vaginal Melanoma and Long-Term Survivors. European Journal of Gynaecological Oncology, 22, 20-22.

[56] Lin, L.-T., Liu, C.-B., Chen, S.-N., Chiang, A.-J., Liou, W.-S. and Yu, K.-J. (2011) Primary Malignant Melanoma of the Vagina with Repeated Local Recurrences and Brain Metastasis. Journal of the Chinese Medical Association, 74, 376-379. http://dx.doi.org/10.1016/j.jcma.2011.06.006

[57] Tcheung, W.J., Selim, M.A., Herndon, J.E., Abernethy, A.P. and Nelson, K.C. (2012) Clinicopathologic Study of 85 Cases of Melanoma of the Female Genitalia. Journal of the American Academy of Dermatology, 67, 598-605. http://dx.doi.org/10.1016/j.jaad.2011.11.921

[58] Vaysse, C., Pautier, P., Filleron, T., Maisongrosse, V., Rodier, J.F., Lavoue, V., Reyal, F., Thomas, L., de la Fouchardiere, A. and Delannes, M. (2013) A Large Retrospective Multicenter Study of Vaginal Melanomas: Implications for New Management. Melanoma Research, 23, 138-146. http://dx.doi.org/10.1097/CMR.0b013e32835e590e

[59] Kirschner, A.N., Kidd, E.A., DeWees, T. and Perkins, S.M. (2013) Treatment Approach and Outcomes of Vaginal Melanoma. International Journal of Gynecological Cancer, 23, 1484-1489. http://dx.doi.org/10.1097/IGC.0b013e3182a1ced8 
[60] Mert, I., Semaan, A., Winer, I., Morris, R.T. and Ali-Fehmi, R. (2013) Vulvar/Vaginal Melanoma: An Updated Surveillance Epidemiology and End Results Database Review, Comparison with Cutaneous Melanoma and Significance of Racial Disparities. International Journal of Gynecological Cancer, 23, 1118-1125. http://dx.doi.org/10.1097/IGC.0b013e3182980ffb

[61] Gokaslan, H., Sismanoglu, A., Pekin, T., Kaya, H. and Ceyhan, N. (2005) Primary Malignant Melanoma of the Vagina: A Case Report and Review of the Current Treatment Options. European Journal of Obstetrics \& Gynecology and Reproductive Biology, 121, 243-248. http://dx.doi.org/10.1016/j.ejogrb.2004.11.048

[62] Sugiyama, V.E., Chan, J.K. and Kapp, D.S. (2008) Management of Melanomas of the Female Genital Tract. Current Opinion in Oncology, 20, 565-569. http://dx.doi.org/10.1097/CCO.0b013e32830b0dda

[63] Abramova, L., Parekh, J., Irvin Jr., W.P., Rice, L.W., Taylor Jr., P.T., Anderson, W.A. and Slingluff Jr., C.L. (2002) Sentinel Node Biopsy in Vulvar and Vaginal Melanoma: Presentation of Six Cases and a Literature Review. Annals of Surgical Oncology, 9, 840-846. http://dx.doi.org/10.1007/BF02557519

[64] Frumovitz, M., Gayed, I.W., Jhingran, A., Euscher, E.D., Coleman, R.L., Ramirez, P.T. and Levenback, C.F. (2008) Lymphatic Mapping and Sentinel Lymph Node Detection in Women with Vaginal Cancer. Gynecologic Oncology, 108, 478-481. http://dx.doi.org/10.1016/j.ygyno.2007.12.001

[65] Karasawa, K., Wakatsuki, M., Kato, S., Kiyohara, H. and Kamada, T., Working Group for Gynecological Tumors (2014) Clinical Trial of Carbon Ion Radiotherapy for Gynecological Melanoma. Journal of Radiation Research, 55, 343-350. http://dx.doi.org/10.1093/jrr/rrt120

[66] Parona, F. (1887) Sarcoma primitivo melanotico fuso-cellulare al setto vescico-vaginale; exportazione del tumore e di porzione della vescico; guarigone temporaria. Ann Univ Med Chir Milan, 279, 241-246.

[67] Janco, J.M., Markovic, S.N., Weaver, A.L. and Cliby, W.A. (2013) Vulvar and Vaginal Melanoma: Case Series and Review of Current Management Options Including Neoadjuvant Chemotherapy. Gynecologic Oncology, 129, 533-537. http://dx.doi.org/10.1016/j.ygyno.2013.02.028 